\title{
Communicative Significance of Traditional Symbols in Oron Local Government Area of Akwa Ibom State: Trend and Prospects in Conflicts Resolution
}

\author{
Israel W. Udomisor ${ }^{1}$, Joseph Umoh Ekpe², Uduak Akpabio Inyang2 \\ ${ }^{1}$ Department of Mass Communication, University of Maiduguri, Maiduguri, Nigeria \\ ${ }^{2}$ Department of Communication on Arts, University of Uyo, Uyo, Nigeria \\ Email: ${ }^{*}$ iriswilson2012@yahoo.com
}

Received 25 June 2014; revised 30 July 2014; accepted 29 August 2014

Copyright (C) 2014 by authors and Scientific Research Publishing Inc.

This work is licensed under the Creative Commons Attribution International License (CC BY). http://creativecommons.org/licenses/by/4.0/

(c) (i) Open Access

\begin{abstract}
This study was carried out to ascertain the "Oro" traditional communication system and modes employed in conflicts resolution. Interviewing key persons, considered in the opinion of these researchers to be custodians of the culture of "Oro" people and thus acknowledgeable in the traditional trends, as well as prominent indigenes of the area, was considered an appropriate instrument for gathering data. In addition, a lot of secondary data were consulted to establish a common link between the past, present and what constitutes "Traditional Communication System" among a people. It was discovered that the communicative significance of the eight (8) selected modesOgbin, Olughu, Oduk Eni, Ndo, Nkang, Obio Utong, Mmong and Ukpong-were still credible and efficacious in transmitting important and strategic messages to the "Oro" people. Ogbin, for instance, still serves as an injunction and is effective in restraining parties in a conflict. Olughu is still employed to establish truth in maters in serious contention, though sparingly due to its dire consequences. The younger generations are not well versed in traditional communication symbols but still adhere when so informed. Therefore, this study espouses trado-modern system of communication to meet the demand of information dissemination retrieval as a critical resource in $21 \mathrm{st}$ century.
\end{abstract}

\section{Keywords}

Communication, Symbols Traditional, Significance Conflict, Resolution

\footnotetext{
"Corresponding author.
}

How to cite this paper: Udomisor, I.W., Ekpe, J.U. and Inyang, U.A. (2014) Communicative Significance of Traditional Symbols in Oron Local Government Area of Akwa Ibom State: Trend and Prospects in Conflicts Resolution. American Journal of Industrial and Business Management, 4, 482-498. http://dx.doi.org/10.4236/ajibm.2014.49054 


\section{Introduction}

There is virtually no end to which communication would not be employed to achieve. Communication can be used either to solve a conflict or start one; communication can create an item or destroy it.

No human being or society can actually exist or function properly since it forms the essence of human interaction, transaction or relationship. Its importance to man is captured in Obasi [1] who says that communication maintains and animates life, functioning as the motor and expression of social activities and civilization.

This can be interpreted thus: communication can be equated with an automobile engine which brings a vehicle to a functional state once the engine is switched on. And, in another vein, McBride [2] posits that communication integrates knowledge, organization and powers and runs as a thread linking man's earliest memory to his noblest aspirations through constantly striving for a better life. This means that wherever or whenever communication occurs, the three core ingredients of man's potentials would be employed to deal with the situation. These include his experience of the past, present and future, his actions and their effects and power as well as his creative energies.

Expectedly, as this amalgamation is activated and re-activated through man's communicative activities with his society, this may result in challenges which, technically, shall be referred to as conflicts here. But these conflicts according to Udoh [3] were never left unsolved because through communication, Nigerians have been able to solve some of their problems in the majority of areas through such means as inter-tribal marriage, language and inter-group relations.

The focus of this work, therefore, is to examine some traditional symbols in communication among the "Oros" of Oron Local Government Area of the present Akwa Ibom State, Nigeria; how these symbols served as various means of communication during the ancient times and how they were useful in solving conflicts in the past, as well as whether those decisions resulting from their uses were binding or not.

\section{Background and History of Oron Local Government Area, Akwa Ibom State, Nigeria}

Oron Local Government Area was created out of the old Eket Division on August 13, 1970, following the directive of the Federal Government of Nigeria that the then South Eastern State be split into more administrative divisions. It is one of the oldest local government areas in Akwa Ibom State besides Eket, Uyo, Ikot Ekpene, Abak, Itu etc. In recent political exercises, four more local government areas have been carved out of Oron Local Government Area-Mbo, Okobo, Udung Uko and Urue Offong-Uruko.

In terms of size, Oron Local Government Area occupies a land mass of 64 square kilometers (25 square miles) and is located some kilometers south-west of Uyo, the capital of Akwa Ibom State. From the sea viewpoint, it is on the west bank of Cross River State, extending from the seaport of Oron by 8.25km along Oron-Uya Oron Road to $8.02 \mathrm{~km}$ along Oron-Ebughu Road and, finally, terminating at 8.20km along Oron-Urue Offong Road. Anwana [4] lists Okobo, Mbo, Urue-Offong and Udung Uko Local Government Areas and the municipal areas of Cross River State, Nigeria, as sharing common boundaries with Oron.

According to the 2006 national census report, Oron LGA has a population of 87,209. There are about 35 villages grouped into the four clans of Afaha Okpo, Ibighi, Idua and Ubodung (Federal Republic of Nigeria, official Grazette [5]). Generally, the people of "Oro" extraction constitute the third largest ethnic group behind the Ibibios and the Annangs, in Akwa Ibom State.

Culturally, the people of Oron speak the "Oro” language and popularly call themselves "Oro Ukpabang” and “Akpakip Oro”. Interestingly, they also speak and understand the Efik language as well as the lingua franca, English Language. Some of their highly educated persons have served humanity in public and private positions.

Traditionally, the predominant occupation is fishing and farming even though the people also engage in local boat building. However, Oron Local Government Area is naturally endowed with oil and natural gas reserves which have contributed enormously to national growth. Besides, it also has various tourism sites such as the National Museum, Beach and the Maritime Academy of Nigeria.

Ultimately, Oron prides itself with rich cultural displays such as Nkwoho/Utang Oro (Oro maiden festival); Akaba dance, Ekombi, Ekong, Nnabo, Tinkoriko, Ekpo Ntagha, Ekpe etc. According to Uya [6], the “Oros” are a distinct group with a rich culture expressed in songs, folklore and dances. Suffice it to say, these all have communicative values embedded in them. 


\section{Communication and Some of Its Definitions}

The consensus among communication scholars is that there are as many definitions as the perspectives from which the term, "communication" is being considered. Katz and Kahn [7] define communication as the exchange of information and the transmission of meaning between a sender and a receiver who swap roles in sending and receiving messages.

These messages are coded in symbols and would have to be decoded through attaching meanings to the objects (symbols). In their opinion, Udall and Udall [8] refer to communication as a process by which a person or group shares and imparts information to another person or group so that both people and the group clearly understand one another. Here, communication is seen as deliberate and intentional and meaning sharing is implied so the choice of communicative objects or symbols would be purposive. Eyre [9] also agrees with this, saying that communication should not just be giving of information but understandable information as well as receiving and understanding the message. He adds that for effective communication to take place, a message to another party should be transferred with the intent of being understood in order to be acted upon by the receiver. In this vein too, Akpan [10] [11] clearly points out that communication is a transactional exchange of message whereby meaning could be shared between the sender and the receiver in such a way as to engender bonds and cooperation.

However, Dominick [12] shows his understanding of communication as the activity whereby a source is involved in the process of encoding a message through a channel to a receiver who, on the other hand, is in the process of decoding the same message with the potential for feedback and the chances of noise interference. Payne (2001) explains that the sender initiates the communication activity while the receiver is the target of the communication. It is to be understood that whatever the sender communicates to the receiver is called the message, the channel is the means of transmitting the message from sender to receiver; feedback is the response which the receiver sends to the sender; interference or noise is anything which blocks or hinders the reception or intended meaning and interpretation of the message or feedback while the time or the place where the communication occurs is the context. In two related works, Gamble and Gamble [13] see communication as the core of humanness. This is illustrated by the fact that when we communicate, we are directly shaping our lives and our world; in essence, the act of communicating with others will help us to initiate, develop, control and sustain our contacts with them.

Meanwhile, Okunna [14] defines communication as an act denoting the sharing of ideas, information, opinions, feelings or experiences between people. In agreement with this, McQuail [15] sees the act of communicating between people as a process of increased commonness or meaning sharing between participants on the basis of sending and receiving messages which, to Littlejohn and Foss [16], makes human life to be experienced in reality. Thus, Wilson [17] posits that communication provides the basis for man to establish a relationship between himself and things in his environment. It could be used to reduce uncertainty which is synonymous with conflict in our vastly challenging world. Wilson [17] says that through communication, we can exchange symbols, establish relationships, banish fear, and blast off the barriers to oneness and understanding.

Furthermore, Hoffman [18] asserts that communication is the transaction involving the meaningful exchange of information between the sender at one end and the receiver at the other end, which entails the encoding, transmitting and decoding of messages, including the process of transformation of the message. Corroborating the afore-mentioned views, Hasan $(2013$, p. 3) submits that "Communication is thus not so much an act or even a process but rather a social and cultural togetherness". In his views, communication can be with oneself, gods, God, and nature and with the people in our environment. Communication might result in conflicts due to such variables as the quality and the quantity of the message received, status and disposition of the audience, time, space, and societal values.

\section{Types and Forms of Communication}

Different types of communication exist. These include intra-personal, interpersonal, group, organizational and mass communication. Forms of communications include traditional or primitive, modern and new or advanced communication technologies. For this work, we shall elaborate on primitive or traditional media shortly although a few descriptions shall suffice here.

Intra-personal Communication: This is communication within an individual and involves the exchange of message between the brain and the sense organs of the body. According to Bitner [19], the messages come in the 
form of electro-chemical impulses which are channeled through the neurons or sensory nerves, which connect the brain with the sense organs in the different parts of the body. For Okunna [20], intra-personal communication makes it possible for an individual to make evaluative decisions based on the information received through the senses, which makes it possible, again, for the person to mediate to oneself and dream [21].

Interpersonal Communication: This type of communication takes place between two or more individuals mostly in a face-to-face encounter with the possibility of feedback [19]. A panel discussion is an example of this type of communication.

Group Communication: This is a type of communication taking place between a group/groups of individuals that share a common interest. A town-hall or club meeting is an example of group communication. Group communication can be either a micro or macro-type. Using examples, Okpoko, op. cit., cites a board or departmental meeting as a micro-type small group communication while Okunna, op. cit., cites a religious assembly or crusade or a political rally as a macro-type communication [21].

Mass Communication: When information is disseminated simultaneously to an audience which is variegated and scattered apart through a channel, we say this is mass communication. The channels here include Radio, TV, Newspaper, Posters, Films, etc. The audience members are a large, faceless, heterogeneous and anonymous group of people scatted all over the world. But it is possible to reach this massive populace through powerful satellites which, according to McBride, op. cit, will transmit information to the whole world at the same time, causing the world to shrink to a global village as predicted by Marshall Mcluhan in 1978.

Organisational Communication: This type of communication is transactional and involves two or more people interacting within a defined environment for the expressed purpose of creating and maintaining benefiting patterns of relationships, making it possible for organizations to serve the desired needs. Koontz [22] defines organizational communication as the transfer of information from the sender to the receiver with the intent that the receiver would understand the message by attaching meanings upon receipt.

What must be emphasized here is the current trend whereby each type could employ one form of new communication technology or a combination to achieve desirable goals of informational transactions than was in the stone or primitive Age. For instance, the use of personal computers and telephones in teleconferences and sending e-mails, the use of satellites in receiving and sending information from source to receivers speedily. Indeed, communication and its practices have improved since the era of Industrial Revolution in Europe.

Now, the forms of communication have been identified mainly as: primitive or traditional, modern and the new advanced, the last of which has just been scratched.

Traditional form of communication aptly titled oramedia by Ugboajah [23] is said to be the product of people's cultural evolvement from birth to death and even beyond death. Popular traditional forms of communication include: symbols, artifacts, implements, dances, instruments, clothing or wears. Studies have shown that no people or society on earth ever advanced to civilization without first passing through primitive communication. One such study is Wilson [24] titled "Traditional Instruments of Communication in Akwa Ibom State".

Then, of course, the modern forms which have been a result of man's consistent but persistent search and inquiry to better his lot. Modern forms include newspapers, the electron or broadcast media (radio, TV, films), the telegraphic media (telegrams, cablegrams) while the new media include computers the internet and the telephones.

Whichever way we may argue, the point must be emphasized that the role of any form and type of communication in shaping the people and the society cannot be underestimated. Suffice to state that man has benefited from communicating with his environment since his existence on earth.

\section{Functions of Communication}

The traditional functions of communication include:

1) It helps to inform, educate and entertain. Man is enabled by learning about trends around the world through what is communicated, being so accurately informed in which he processes is also better educated and satisfactorily entertained.

2) It helps to create, define and maintain relationships through mutual sharing and understanding of what is communicated. Whatever that is not beneficial for mutual co-existence can be re-defined to fit in with acceptable norms of the society.

3) Communication serves as a sentiment by providing safe-guards to man/society so that they could avoid pit 
falls which have sunk unwary cultures elsewhere.

However, management study Guide in its website further elaborate the functions of communication as follows:

4) Communication provides information to man/society for an effective decision-making process which helps in the identification and assessment of alternative course of action.

5) Communication promotes motivation by informing and clarifying the people/society about what tasks to undertake for their benefits, the manner to undertake the tasks and how to improve on societal expectations if they are not optimum.

6) Communication helps to alter/shape the individual's attitude to societal norms for the fact that being well-informed, the person will have better attitude than a less-informed individual.

7) Finally, communication assists in controlling the process of man evolving to a better state than previously, because the society is a dynamic entity, and as man continually strives to better his lot, it behooves on him to adhere to certain principles and societal guidelines necessary for him to attain his goals in life.

\section{Communication and Conflict}

Whatever the definitions are, we are looking on communication as the human activity which begins when a source who has a message shares it through a channel with a receiver with the possibility of feedback. The feedback may be desirable or undesirable.

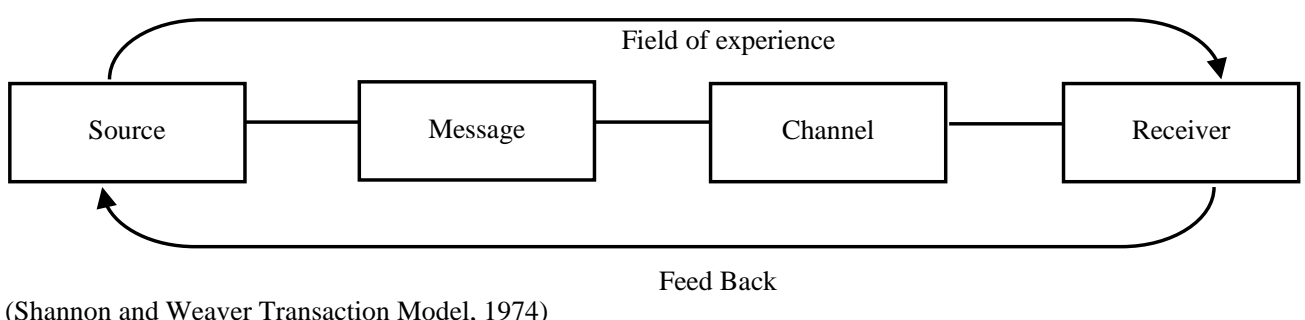

There is also the possibility of interference (noise) which could result in undesirable feedback. If it is undesirable (and it could often be), then a conflict situation has arisen. What must be done is to initiate further communicative activities between the source and the receiver (while fine-tuning the channel for optimum result) until the dissonance (or noise) is substantially reduced. We ought to under that conflict cannot be entirely eliminated since communication is an ever-evolving process and chances are that further communication (relationships, meaning sharing, actions) may bring fresh conflicts into the system.

Hence, with purposive communication, conflicts could be pragmatically managed in order to advance in meaning sharing. Noise in communication context could denote misunderstanding, uninterpreted signal, strange symbols, and general loss of communication link. On the other hand, an interpreted signal and subsequent response to the said signal is called feedback.

Now the questions to ask are: what is conflict? What is the relationship between conflict and communication? How are communications applied in the resolution of conflicts? This paper shall attempt to answer these and any other question which may arise in the course of discussion.

In defining conflict, we shall rely on the opinions of three scholars. Owens-Ibie [25] defines conflicts as a product of life and living. The definition proposes that conflict is an inherent part of human because of man's communication with other beings. Ibrahim [26] defines conflict as a state of disagreement or argument between people, groups or countries. This definition supposes that conflict arose because what was communicated was disagreed upon, this being also that certain vested interests were threatened by a misunderstanding in communication. However, Udomisor [27] sees conflict as a by-product of plurality in a free environment which allows opinions and feelings to be fully and freely expressed, adding that conflict develop as a result of differences in opinion, attitude and behavior. Conflict may also develop from the differences in the multifarious orientations or interactions in a given system or society.

If by interaction we do mean communication, then we could say there is a relationship between communication and conflict in so far as the former may bring about the latter in the event of a misunderstanding or differences in values. 
Then, the question is: Is Conflict necessary in communication? We shall attempt an answer with what Udo Etuk [28] says:

Conflicts are often perceived as necessarily bad. We equate conflicts with fights, clashes, disturbances, absence of peace, understanding and concord. A conflict situation is something most persons would want to see resolved as soon as possible.

In his view, there could be no cessation of conflicts as far as there are people who thrive on conflicts - for instance, the mercenary soldier who makes a fortune during wars; the armed robber whose operations conflict with everything a civilized and orderly society would accept. Although these are exceptional cases, he also says that most persons do not see conflicts as desirable.

Is conflict desirable or not? Udo Etuk, op. cit., argues that, rather than being necessarily evil, conflicts are a necessary part of any living system; they would only cease where the system is dead. Cursorily, there is no totally dead system because even in an authoritarian system of dictatorship, where there appears to be a muffled and silent opposition, there would still be conflicts.

An Ephesians philosopher named Heraclitus proposed that strife or conflict was the essential characteristics of life. "We must know", says he, "that war is common to all and strife is justice; and that all things come into being and pass away through strife", Heraclitus felt that to pray for the cessation of conflicts as the poet Homer did, is seeking to be misguided. According to the ancient philosopher, if strife ceased, the universe itself would grind to a halt.

Continuing in his dialectical discourse, Udo Etuk, op. cit., buttresses the essence of conflicts in communication with the facts of birth and death, growth and decay, constancy and change. He says before fire is kept alive, there would be consummation of other substances such as wood, kerosene and matches. Human beings live by destroying other animals and plants as food. Looking at these as conflict situations of one thing encroaching upon another, Udo Etuk maintains that conflicts remain a fact of life and therefore, inevitable. He adds that conflicts only require a little adjustment for, like the ancient philosopher Heraclitus once said, "any system was an attunement of opposite tensions, like that of the bow and lyre”.

\section{Traditional Mode of Communication}

As stated already in this paper, traditional communication (tradocom) or primitive communication is a harbinger of the modern systems. It has its value and occupies a prime place very well in the society. Ugboajah [23] posits that traditional communication is basically a product of the interplay between a traditional community's customs and conflicts, harmony and strife, cultural convergences and divergences, culture specific tangibles, interpersonal relations, symbols, and codes, moral tradition which include mythology, oral literature (poetry, storytelling, proverbs), masquerades, witchcraft, rites and rituals, music, dance, drama, costumes and, then, similar abstractions and artifacts which demonstrate a people's factual symbolic and cosmological origin and existence right from birth to death and even beyond death. All these form a set which Ugboajah, opcit, calls folk media or oramedia or tradomedia.

Wilson [29] [30] maintains that traditional communication has been in practice among Akwa Ibom people for thousands of years with the use of various instruments and methods. Wilson [30] particularly notes traditional communications as "the easiest form of communication used by every society wherever they existed before the innovation of the more sophisticated forms". He adds that tradocom is actually credible, low-cost, interactive, authoritative and quite popular. Perhaps, also, it is quite easily available.

Communication scholars such as Ugboaja, Wilson, Okunna, Ekwelie, Okonkwo, and Ore believe that African societies would lose much of their vibrancy and tenacity were it not for the traditional (local, primitive) media and channels. For instance, Ekwelie and Okonkwo [31] maintain that despite the intrusion of the electronic age, the folk media have survived the earliest times into the modern dispensation and still retain both their basic modes and significance. Ugboajah [23] states that the traditional modes of communication existed primarily to serve the economic, social, religious and political functions as determined by the leaders at a given time. Till date, they are still relevant in community mobilization. Okunna [14] has averred that most of the rural communities still share information traditionally today among their people, for instance from mouth to mouth.

In taxonomy form, Ore cited in Uche (2002) has listed the media of traditional communication as facial expression and gesture, touch, pictures and visual signs, music, dance and written or unwritten words. Okunna [20] hints that before the development of language, people communicated mostly through touch (tactile communica- 
tion) and vocal signs.

Wilson [29] gives different form of traditional instruments of communication as follows:

1) Aerophones: These are traditional instruments in which sound is produced by the vibration of air in a column such as flutes, reeds and up mouthpiece instruments, whistles, trumpets and horns (deer, ivory, cow-horns).

2) Idiophones: Self-sounding instruments made up of sonorous objects which may be stamped (with the feet), shaken, scraped, beaten or plucked. Examples include bells, gongs, vessels (pot drum), xylophones, rattles and of course, the slit wooden-drum (obodom).

3) Membranophones: These are instruments whose sounds are produced by vibrating their stretched membrane when beaten or struck. Instruments in this group are the skin drums ("ibit”, "ikpeti” or "ekomo").

4) Chordophones: These are instruments which sounds are produced by the vibration of strings, which must be lifted from the body before the sounds are made. Chordophones are principally musical rather than communication instruments but their relevance here lies in the fact that the sound/music they produce communicates the "message" to the audience. Examples include bows ("ndido uruk"), fiddles, harps, flutes.

5) Floral media: These belong to the group called "silent" articulators of communication. The floral media include selected flora of the local vegetation (plants and grasses) for communcating certain messages or ideas within the socio-cultural and political contexts of the display or presentation of the plants or leaves. Some of these are "boundary or beacon" plants used in marking the plots of lands ("okono"), the young, unopened palm frond ("eyei”) and other leaves (e.g. "nyama”, "mkpatat”). Florals sometimes serve as newspapers or messages on bill board. Among the Akwa Ibom people, the palm frond-“eyei”-remains, perhaps, the most important. Known as "nwed ikpaisong" (the supreme book), the "eyei" has force and credibility and, when displayed or presented, no one defies its message for fear of dire consequences or supernatural retribution.

6) Symbolography: Is the use of cryptic representations made on hard or soft surfaces of clothes, walls, bamboo or the ground for communication. A few examples of symbologrpahy are "nsadang" and "nsibidi". According to Wilson, op. cit., the "nsadang" is a small decorated and sharpened splinter made from the dry branch of the raffia palm tree. Anyone who received "nsadang" is being warned of danger. On the other hand, "nsibidi" is a sign language which communicates affinity among members of certain "cult" societies such as "Ekpe”, "Ekpo" and "Inam".

7) Objectifics is a form of traditional communication in which the object refers to a thing, a concept or an event. Examples include kolanuts, charcoal, white fowls, eggs, feather, etc. As a concrete presentation, it may have a limited meaning or may have a universal application or significance.

8) Symbolism is another form. It employs technical and non-technical means to communicate. Symbolism is the communication practice of using symbols to represent things, messages of information or by investing things. Examples: the kiss symbolizes love, fondness; hugging expresses love or a welcome to a friend; a handshake expresses love or a please-to-meet-you attitude; a hair-do may express rebellion, sadness, happiness, occupation, etc; genuflection/prostration shows respect while a clenched fist shows solidarity, defiance, or an acknowledgement of the symbolistic inferior position reverence of the person communicating the message.

9) Furthermore, there is the extra-mundane mode which is real or imagined, yet it is believed to take place between the living and the dead, or between the living and the supernatural or supreme beings and vice versa. There are two types of extra-mundane communication - one is the graphic form and the other, non-graphic. Examples of graphic types are obituaries, in-memorian notices and tombstone messages. The non-graphic types are incantation, ritual, prayer, sacrifice, vision, speaking in tongues and contemplation, etc.

10) Finally, there is the institutional mode of communication which involves the use of cultural or traditional institutions to communicate aspects of the people's life, for instance, culture, entertainment, education, information and general knowledge. Examples of institutional communication are ceremonies relating to marriage, chieftaincy titles, initiation into societies/cults/shrines and masquerade groups.

Wilson [30] re-classified traditional communication into the following modes:

1) Instrumental mode: This consists of idiophones, aerophones, membranophones and symbols.

2) Demonstrative mode: This involves the use of music and signals in communicating with people.

3) Iconographic mode: This involves the use of objects and floral media to communicate.

4) Extra-mundane mode: This is communication between the visible and the invisible through such means as rituals, sacrifice, prayer, etc.

5) Visual mode: This involves the use of colours dressing, appearance and, generally, body comportment to communicate certain feelings and emotions or attitudes. 
6) Institutional mode: This mode employs traditional institutions which symbolize the general behavioural patterns akin to such institutions.

\section{Traditional Communication, Symbolism and Meaning Sharing}

There is no gain-saying what significant roles traditional communication has played in the overall development and normalization of a people's pattern of living before the era of modern communication. No doubt, the former has served as the herald of the latter. Thus, for its contribution and importance, traditional communication has received quite a lot of scholarly attention in the field of communication. Hence, substantial volumes have been documented and will bear a mention here.

Assuredly, there exists a relationship between communication, symbols and meaning sharing. Attention to symbols will result in the need for sharing of meaning. Where there is meaning sharing, then we say there is effective communication. Where meanings are not shared, communication is said to be ineffective and could lead to conflict which must be solved. However, whether meanings are shared or not, communication has taken place. This brings up the place of symbols in communication.

Williams [29] states that symbolic communication is a part of human evolution and that humans are, distinctively, symbol users with the main symbol system being language. What then is a symbol?

Shaefer and Lamn [32] define symbols as the gestures, objects and language which form the basis of human communication system, which are found in verbal and non-verbal forms.

Ritzer [33] defines symbols as social objects used to represent (stand for, take the place of) whatever people agree those objects should represent, adding that not all social objects stand for others but those that do, are said to be symbols, and people often use symbols to communicate about themselves.

Ansu-Kyremeh [34] shows that symbolographic communication is needful for members of an exclusive club such that they could share between themselves only what they did not want others to know. The Ekpe society and its mode of communication fits into this description with its cryptic representation through a pseudo writing called "Nsibidi" with which members communicate between themselves.

Interestingly, Rueben [35] concurs there is a fool-proof relationship between symbolism, culture and communication where the human being possesses such capacity to initiate communication and meaning sharing through symbols, language, knowledge, meanings, rules, values and rituals. He says this in turn gives definition, form/shape top outgoing relationship which makes it possible to pass along certain finer elements of a people's culture from one generation to the next and from one society to another.

However, Crowley (2000) has said that symbols can be complex leaving the meaning to evolve with the culture. What this means is that symbols are culturally defined, for a particular symbol may mean different things to different cultures.

This explains the view held by Gamble and Gamble [13] that people from different cultures perceives stimuli differently, at least in part and whatever they communicate will be based on that experience because of their cultural differences.

Based on the above assertions, it can be seen that differences will brew cultural and by implication, communication conflicts. Even though conflict is a necessary "evil" it has to be solved for the world to move on. Thus, it can be solved through effective communication. Hence, Okunna [14] has canvassed that a commoness must be established between the people involved in any communication process before communication could be effective. And Udeze [36] has stressed that both the sender and receiver of information must operate on the same frequency in terms of sharing meaning in the same language and symbols used for effective communication, ditto for conflict resolution.

Similarly, William [29] has deposed to similar sentiments that owing to the fact that every culture has a unique way of communicating with symbols, there is the need for meanings to be shared if, effective communication must take place and conflicts resolved.

So far, the advantages derivable from traditional communication cannot be over-emphasized neither can the essence of meaning sharing be under stressed. Meaning sharing engenders cohesion, mobilization and unity. Thus, Eneobong [37] points out that traditional communication among the Annang ethnic group of Nigeria was helpful in the maintenance of peace and order, promotion of unity, harmony and good morals, shoring up respect for elders and constituted authorities, the enforcement of laws and regulation of activities in the society, the prevention of abominable acts as well as the promotion of good conduct, and served as a megaphone for infor- 
mation dissemination.

\section{Traditional Communication-The Akwa Ibom Experience}

In a well-researched work, Wilson [29] notes: “Akwa Ibom people have been communicating among themselves for thousands of years using a variety of instruments and methods... students of communication may do well to use this (the researched work) as a resource base for more intensive and incisive research into various aspects highlighted here”. Udoekong [38] has taken the challenge producing quite some revelations in the aspect which our current effort has relied upon. However, Udoh [3] has provided insight when he notes as follows:

1) The guest-host relationship is one attempt to resolve cultural conflicts among Nigerians.

For instance, among the Akwa Ibom People, a well-kept house symbolizes or stresses a robust guest-host relationship. Thus, upon the arrival of a guest, the host receives him with symbolic greetings and is made to settle. After some interval of humorous conversation, the guest is presented with dainty dish. Neighbours do call in to wish the visitor well and, if he has to spend the night with the host, then he is welcome. It would be humiliating to be thought incapable of properly treating a guest just as it is shameful not to be capable of resolving conflicts in society.

2) The drum and the horn could be used to transmit messages through sound, communicating over long distances. For instance, when an exiled criminal took asylum in a remote territory, the talking drum would be used to announce his departure to the public to avoid inter-state conflict.

3) The elephant tusk (nnuk enin) was used extensively in Annang and Ibibio lands to summon heads of villages together for the settlement of major conflicts such as land and boundary disputes, murder, arson, adultery and witchcraft. The "nnuk enin" served as a telegraphic trumpet and was also used for alerting inter-group co-operation in times of crises.

The communicative implication here are that in the first case, the well-kept house, the symbolic greetings and well wishes, and the dainty dishes communicate acceptance and the disposition for both the host and the guest in cultivating good mental attitude towards one another. Also, it stresses effective inter-group interaction; both of these are immensely important and essential as means for communicating a relationship and, possibly, reducing or resolving conflicts in the Nigerian society. In the second and third instances, the drum and the telegraphic trumpet clearly show that as traditional instruments of communication, the oramedia are a powerful means of arresting divergence in communication to a convergence, thereby eliciting mutual understanding and co-operation among members of various societies.

In the advancement of the importance of traditional means of communication in resolving cultural conflicts, Effanga [39] posits that typical relationships such as "Ukod", "Ayeyin" and "Iman" are veritable but powerful instruments among the Ibibios of Akwa Ibom State (and we dare to add, other societies which accord respect to these lines of kinship). He reports that "ukod" (in-law), the "ayeyin" (grandchild) and the "iman" (kindred) communicate carefulness in inter-personal dealings between and with fellow human beings lest one should break a traditional taboo and be destroyed by the gods and the ancestors. It should be noted that most Ibibios believe in traditional religion which tenets include elements of extra-mundane communication.

With regards to the importance of Akwa Ibom indigenous culture and communication, Antia [40] posits:

All traditional instruments, items, elements, objects and symbols conspire to give a jumbo personality and enviable dignity to communities and loudly or silently, consciously or unconsciously, but effectively and spontaneously, deliver messages to people. The mere sight or sound of these instruments, elements, objects and symbols automatically communicates particular meanings to indigenes... (and) safeguard the identity of the people.

Some of these instruments which symbolize or communicate traditionally in Akwa Ibom State are: "Ayei”, “Udung”, “Nnuk enin”, “Ayaang Ubong”, “Mba-mba”, and “Akaan-Kaan” among others.

Antia, op. cit. explains further as follows:

1) The "eyei", is worn on the heads, hands, legs, or the bodies of people who win contests to show happiness and victory. Tied in a special way or held, it could convey a variety of messages:- Tied to or hung on items and properties, it invokes a ban not to tamper with, encroach upon or intrude against; when tied across a road or path, it means restriction for non-qualified people to keep off. When a grandson holds and shakes between two warring factions, it means a plea for cessation of hostilities for peaceful negotiation to begin. When woven together into a mat shape, it could provide coffins for deceased traditional chieftains and members of the Idiong, Inam, Ekong, and/or Mbiam societies or cults. When carried in the mouth (in between the lips), this portrays that the 
carrier is on special mission and is forbidden from talking to people except those to whom he is sent.

2) The “Ayaang Ubong” (Kingship broom) symbolizes the authority of a ruler. The "Ayaang Ubong” is composed of the ribs of young palm fronds made into brooms with curved or coiled ends. This way, it constitutes an insignia of office for a traditional ruler. The ruler's messenger who carries this "broom" is respected, protected or highly honoured by the ruler's subjects or accorded similar privileges as accruing to the messenger's principal.

3) The "Akaankang” (sword) symbolizes strength, power and bravery. It signifies war as such a display of the "Akaankang” before enemies indicates the readiness for war.

4) Furthermore, the Lion's or Leopard's teeth ("Edet Ekpe”) also symbolizes authority and the mere sight of it on a traditional ruler's neck ought to generate humility/submission in his subjects as they are expected by law or force to defer to the ruler.

In similar view, Wilson [41] lists, among others, the purposes for which the ivory tusk (nnuk enin) is meant:

1) Settling quarrels

2) Informing citizens of the death of kings, serious calamities and other grave occurrences

3) Placing injunction over disputed properties

4) Offering the final word or judgment on issues

5) As a medium of information about important festivities for members of secret societies.

Of course, Udosen [4] posits that among the iconographic symbols in Ibibioland, the "nnuk enin" stands for royalty, and serves as an instrument for conflict resolution as well as indicate the prohibition on the use of a property under dispute. The white clay (Ndom) symbolizes happiness, success and honour. It is also a symbol of goodluck. When a mother is delivered of a child, she and her admirers/well-wishers usually adorn themselves with ndom to celebrate the glad tidings. Again, when someone escapes from a misfortune, he/she dabs self to show the joy and celebrate the good fortune. On the other hand, the charcoal is emblematic of disgrace, failure and shame, explaining the use of charcoal on the thief who is caught in the misdemeanour. Others include palm fronds (ndak eyop) used to indicate happiness, festivity and welcome' dracaena plant (okono) used for boundary demarcation, restriction of entry and symbol of traditional cleansing, while the plantain stem (ekpat ukom) can sometimes be representative of the declaration of dispute over any property and, otherwise, serves as a call for redress of a bad situation.

Earlier on Ekong [42] gives an indepth analysis of certain symbols in Ibibio land and Oron. These include:

1) The saliva: The use of saliva in inter-personal relationship speaks volumes traditionally. If a child misbehaved and brought shame on his family, the father could spit on the child, and then denounce and disown him. The implication here is that on the death of the father, such a shameful child may not see the "father's face" nor take part in any of the burial ceremonies. But this could be resolved by a cleansing sacrifice or exercise whereby the father recant his earlier stand and then pray for the "offending” child.

2) Totems: These are collective religious objects considered to possess supernatural or mystical powers for a group and for which the group can sometimes be named after. Besides the Ibibios, the "Oros” (people of Oron origin) kept carved figures representing the ancestors at the family shrines as a form of traditional worship; hence this served as objects of traditional communication [42].

3) Institutionalised elements of Justice: Ekong [42] posits that "mbiam” appeared to be the greatest symbol of justice and social control in the traditional Ibibio society. Anyone who wanted to prove his/her innocence would swear on "mbiam". Once "mbiam" was mooted in the settlement of a dispute or conflict, bribing of judges and the miscarriage of justice became rare occurrences because it was believed "mbiam” has such potency. Other items of institutional value used to check and prevent crimes, foster interpersonal relationship and resolve conflicts include: “mbritem” (ginger lily or bush cane); “mkpatat” (Ferns; selaginella); “mkpok ekwong” (snail’s shell); “oboro” plant and “okon” tree (Dracaena Fagan) among others. And, of course, the ubiquitous "eyei”, (young palm fronds) used as injunction to or abet further nuisance.

\section{Research Design/Methodology}

Descriptive survey became imperative in this study as it sought to determine the traditional symbols of "Oro people” of Oron Local Government Area of Akwa Ibom State, their effectiveness and validity as means of communication, especially when deployed in conflicts resolution. This was necessitated by the demands of qualitative research which connotes using language to analyse and discuss or in other words, describe a given phe- 
nomenon.

The Oro people, found in Oron Local Government Area, constituted the population of this study. Interview sessions were held with discretely selected personalities of Oro ethnic extraction. Also, 350 copies of questionnaire were administered (only 288 could be retrieved), using a cluster sampling technique, with 10 research assistants working for four days, under close supervision. This approach became necessary as most respondents needed to be fully versed with the meaning, intention and purpose of the study, and acted mostly in their own terms, which only the affinity of language could break the artificially created barriers. Details are as follows:

Day 1: Interview with His Royal Highness, Ofong Francis Okon Eyo, Clan Head Afaha Okpo, Oron LGA.

Distribution of copies of questionnaire to 250 respondents within the urban settlement known as "Akan Obio" (i.e. the metropolis), of the said copies, 233 were retrieved within four days due to transportation and distance hiccups.

In the rural area called Uya Oron, 100 copies were distributed and only 55 retrieved within two days (reason for the decline in the copies retrieved being level of literacy).

\section{Oron Traditional Symbols as Means of Resolving Conflicts-Their Impact and Extent}

Two traditional rulers and a prominent stakeholder in Oro Nation were spoken to, namely: His Royal Majesty, Ofong Odiong Edet Akan, the Paramount Ruler of Oron His Highness Ofong Francis Okon Eyo, the Clan Head of Afaha Okpo, Oron Local Government Area, and Hon. Chris Abasieyo former Commissioner for Information, Akwa Ibom State. These interviews are captured in the appendix section of this study (A \& B). Their views were that some of these symbols discussed here under are not only part of their cultural heritage but also means of communication and resolution of conflicts. HRM named these as "Ogbin” (palm fronds), "Olughu” (juju), “Oduk Oni” (elephant tusk), “Ndo” (white clay), “Nkang” (charcoal), “Obio Utong” (special string), "Mmong” (water), "Ukpong” (horn), etc.

Corroborating Ofong Akan's assertion, Ofong Eyo stated that the meaning in "Ogbin” for instance, is traditional injunction; "Olughu” symbol of justice and "Obio Utong” (indication of warning) are very clear to an “Oro” indigene, that any act of disrespect for such symbols could attract sanctions and the payment of stipulated fines.

To substantiate the views of these prominent citizens of Oron, 350 copies of questionnaire were administered in "Akan Obio" (i.e. Oron Metropolis) and Uya Oron; only 288 could be retrieved. However, the data gathered, which is here presented in tables, were found to be very useful in establishing the authenticity of Oron traditional symbols deployed in conflict resolution.

\section{Presentation of Data}

Table 1 indicates that of the 288 respondents, 217, representing 75.35\% were males and $71 \%$ or $24.65 \%$ were females.

In Table 2, 36 respondents, representing 12.5\% were within the age bracket of 18 - 25 years, 45\% or 15.63\% of them were aged between 26 - 30 years, $57 \%$ or $19.80 \%$ were between the ages of 31 - 40 . Those within $41-50$ age bracket were $83 \%$ or $28.81 \%$ while 67 respondents or $23.26 \%$ were adults aged 51 years and above.

According to Table 3, 17.55\% (51 respondents) had no formal education; 19.68\% (57 respondents) had First School Leaving Certificate; 24.47\% (70 respondents) had WASC/SSCE; 19.5\% (55 respondents) were holders of NCE/Diploma; 12.77\% (37 respondents) had HND/B.Sc; and 6.38\% (18 respondents) were holders of M.A/M.Sc.

Table 4 shows that 283 (98.14\%) of the respondents said they were Christians while only 5 (1.86\%) practiced African Traditional Religion.

Table 1. Gender distribution of respondents.

\begin{tabular}{ccc}
\hline Gender & Frequency & Percentage \\
\hline Male & 217 & 75.35 \\
Female & 71 & 24.65 \\
Total & $\mathbf{2 8 8}$ & $\mathbf{1 0 0}$ \\
\hline
\end{tabular}


Table 2. Age distribution of respondents.

\begin{tabular}{ccc}
\hline Age & Frequency & Percentage \\
\hline $18-25$ & 36 & 12.5 \\
$26-30$ & 45 & 15.63 \\
$31-40$ & 57 & 19.80 \\
$41-50$ & 83 & 28.81 \\
51 and above & 67 & 23.26 \\
Total & $\mathbf{2 8 8}$ & $\mathbf{1 0 0}$ \\
\hline
\end{tabular}

Table 3. Distribution of respondents by educational Background/Qualification.

\begin{tabular}{ccc}
\hline Qualification & Frequency & Percentage \\
\hline No. formal education & 51 & 17.55 \\
FSLC & 57 & 19.68 \\
WAEC/SSCE & 70 & 24.47 \\
NCE/OND & 55 & 19.15 \\
HND/B.Sc & 37 & 12.77 \\
M.A/M/Sc & 18 & 6.38 \\
Ph.D & - & - \\
Total & $\mathbf{2 8 8}$ & $\mathbf{1 0 0}$ \\
\hline
\end{tabular}

Table 4. Distribution of respondents by religion.

\begin{tabular}{ccc}
\hline Religion & Frequency & Percentage \\
\hline Christianity & 283 & 98.14 \\
Islam & - & - \\
African Traditional Religion & 5 & 1.86 \\
Others & - & - \\
Total & $\mathbf{2 8 8}$ & $\mathbf{1 0 0}$
\end{tabular}

The data from Table 5 show that 67 (23.40\%) respondents said the Ogbin medium was useful as an instrument of traditional injunction; 34 (11.97\%) favoured its use for restraining disputants; 29 (10.11\%) valued its use for placing bans on objects and property; 25 (8.51\%) said it is used for summoning people to meetings while 133 (46.01\%) said the medium performed all the stated functions.

According to Table 6, $17 \%$ or 6.12\% respondents said that Oduk Oni stood for traditional injunction prohibiting the use of a property under dispute, $116 \%$ or $40.16 \%$ said it represented royalty and rulership; $23 \%$ or $7.98 \%$ said it was used for settling disputes while $132 \%$ or $45.74 \%$ indicated that the traditional symbol served all the specified communication functions.

The data on Table 7 reveal that 50, representing 17.29\% took the significance of Ndo to be happiness, success and honour; 47 , representing $15.16 \%$ selected its significance as a gift of friendship, goodwill and blessing; 29 , representing $10.11 \%$ said its use indicated innocence from accusation while $165 \%$ or $57.45 \%$ said it was useful for all the three specified functions.

Table 8 shows that of the total number of respondents, 53 (18.36\%) selected Nkang as an emblem of disgrace, failure and shame; for 34 (11.97\%), it represented misery, dejection and frustration; 60 (20.75\%), said it was used to mark a confirmed thief, witch or wizard, while 141 (48.94\%) settled for the forth option which said it would serve all the three state purposes.

Table 9 shows that $72 \%$ or $25 \%$ of the respondents said that Olughu stood for prohibition of entry into a place 
Table 5. Significance of Ogbin (young palm frond).

\begin{tabular}{lcc}
\hline \multicolumn{1}{c}{ Significance } & Frequency & Percentage \\
\hline Instrument of traditional injunction & 67 & 23.40 \\
Restraining disputants & 34 & 11.97 \\
Placing ban on objects and property & 29 & 10.11 \\
Summoning to meeting & 25 & 8.51 \\
All of the above & 133 & 46.01 \\
Total & $\mathbf{2 8 8}$ & $\mathbf{1 0 0}$ \\
\hline
\end{tabular}

Table 6. Significance of Oduk Oni (elephant tusk).

\begin{tabular}{lcc}
\hline \multicolumn{1}{c}{ Significance } & No. of Respondents & Percentage \\
\hline Traditional injunction & 17 & 6.12 \\
Prohibits use of property under dispute & - & - \\
Represent royalty and rulership & 116 & 40.16 \\
Used for settling disputes & 23 & 7.98 \\
All of the above & 132 & 45.74 \\
Total & $\mathbf{2 8 8}$ & $\mathbf{1 0 0}$ \\
\hline
\end{tabular}

Table 7. Significance of Ndo (white clay).

\begin{tabular}{lcc}
\hline \multicolumn{1}{c}{ Significance } & No. of Respondents & Percentage \\
\hline Happiness, success or honour & 50 & 17.29 \\
Gift of friendship, goodwill and blessing & 47 & 15.16 \\
Shows innocence from accusation & 29 & 10.11 \\
All of the above & 165 & 57.45 \\
Total & $\mathbf{2 8 8}$ & $\mathbf{1 0 0}$ \\
\hline
\end{tabular}

Table 8. Significance of Nkang (Charcoal).

\begin{tabular}{lcc}
\hline \multicolumn{1}{c}{ Significance } & No. of Respondents & Percentage \\
\hline Emblem of disgrace, taboo and shame & 53 & 18.36 \\
Represents misery, dejection and frustration & 34 & 11.97 \\
Used to mark a confirmed thief, witch or wizard & 60 & 20.75 \\
All of the above & 141 & 48.94 \\
Total & $\mathbf{2 8 8}$ & $\mathbf{1 0 0}$ \\
\hline
\end{tabular}

Table 9. Significance of Olughu (Juju).

\begin{tabular}{lcc}
\hline \multicolumn{1}{c}{ Significance } & No. of Respondents & Percentage \\
\hline Prohibition of entry into a place or property & 72 & 25 \\
Used to establish truth of a matter & 55 & 19.15 \\
Symbol of Justice & 50 & 17.29 \\
All of the above & 111 & 38.56 \\
Total & $\mathbf{2 8 8}$ & $\mathbf{1 0 0}$ \\
\hline
\end{tabular}


or property; $55 \%$ or $19.15 \%$ said it was used to established the truth of a matter; $50 \%$ or $17.29 \%$ said it was a symbol of justice while $111 \%$ or $38.56 \%$ respondents said it could represent all the options provided.

From Table 10, 66 respondents, representing 22.87\% said that the use of Obio Utong indicated grievance over some bad occurrence; 44 , representing $15.16 \%$ regarded it as a reminder of a taken decision; 70 representing $24.47 \%$ said it indicated warning, while 108 , representing $37.5 \%$ settled for all the options.

The data from Table 11 show that 78 (27.13\%) respondents said Mmong was useful for peaceful settlement of conflicts, 67 (23.14\%) said it represented rejection and disgrace; 39, (13.56\%) said it was significant for pacifying the blood of a slaughtered animal; while 104 (36.17\%) respondents said it was significant for all the provided options.

The data on Table 12 reveal that 48, representing 16.49\% said Ukpong was used for summoning people to meeting; 75 , representing $26.06 \%$ indicated that it was used by traditional societies to send special messages; 41 , representing $14.36 \%$ said it was significant for alerting people to a problem that needed urgent solution, while 124, representing $43.09 \%$ chose all the provided options.

Table 13 indicates that 256 respondents, representing 88.83\% said that even without explanation, they would indeed understand messages rendered through the media of symbols selected for this study; while 32, representing $11.17 \%$ of those sampled said they would not understand the symbols as such.

According to Table 14, 202 (70.21\%) of the respondents said they would regard the use, as well as the messages rendered through the selected symbols as valid; 58 (19.95\%) were of the opinion that such channels were outmoded; while 28 (9.84\%) supported the view that they would regard the selected symbols and their meanings as being contrary to their religious beliefs.

Table 10. Significance of Obio Utong (Special string).

\begin{tabular}{lcc}
\hline \multicolumn{1}{c}{ Significance } & No. of Respondents & Percentage \\
\hline Indicates grievance over some bad occurrence & 66 & 22.87 \\
Reminder of a taken decision & 44 & 15.16 \\
Indicates warning & 70 & 24.47 \\
All of the above & 108 & 37.5 \\
Total & $\mathbf{2 8 8}$ & $\mathbf{1 0 0}$ \\
\hline
\end{tabular}

Table 11. Significance of Mmong (Water).

\begin{tabular}{lcc}
\hline \multicolumn{1}{c}{ Significance } & No. of Respondents & Percentage \\
\hline Indicates peaceful settlement of conflict & 78 & 27.13 \\
Represent rejection and disgrace & 67 & 23.14 \\
Pacifies blood of slaughtered animals & 39 & 13.56 \\
All of the above & 104 & 36.17 \\
Total & $\mathbf{2 8 8}$ & $\mathbf{1 0 0}$ \\
\hline
\end{tabular}

Table 12. Significance of Ukpong (Horn).

\begin{tabular}{lcc}
\hline \multicolumn{1}{c}{ Significance } & No. of Respondents & Percentage \\
\hline Summon to meeting & 48 & 16.49 \\
Used by traditional societies to send special messages & 75 & 26.06 \\
Alerts people to a problem needing urgent solution & 41 & 14.36 \\
All of the above & 124 & $\mathbf{4 3 . 0 9}$ \\
Total & $\mathbf{2 8 8}$ & $\mathbf{1 0 0}$ \\
\hline
\end{tabular}


Table 15 shows that $172 \%$ or $59.84 \%$ of the total respondents sampled indicated that Oro traditional symbols were not less effective than modern media of communication whereas $116 \%$ or $40.16 \%$ said Oro traditional symbols were less effective than modern media of communication.

\section{Discussions of Findings}

Communication is said to be effective when meaning, as intended by the source of the message, has been shared with the receiver. Thus, in assessing the communicative significance of traditional symbols in Oron Local Government Area deployed in conflict resolutions, the responses elicited through the interviews and questionnaire can be summarized as follows:

1) “Ogbin” (Eyei/Young Palm Fronds): The "Oros” recognize Ogbin as an instrument traditionally used for injunction which forbids entry into a place by unqualified persons. It also can be used to prohibit the use of a property under dispute. Thus as instrument for conflict management, the "Ogbin" is highly revered and will remain so on the disputed property until the resolution of the conflict, before it can be discarded.

2) “Olughu” (Mbiam/Juju): Among “Oro" people, the Olubhu is also used to indicate the prohibition of entry into place or property; it is also a symbol of justice and a medium for establishing the truth over a matter in contention because anyone who swears falsely will be guilty of perjury and is believed to die. This submission tallies with Ekong (2001) that "mbiam" or "olughu" is the greatest symbol of justice in traditional communities of Akwa Ibom State.

3) “Oduk Eni” (Elephant Tusk/Nnuk Enin): Though largely a symbol of authority and royalty, once placed over a disputed property, it serves as an instrument for conflict resolution among opposing groups.

4) "Ndo" (White Chalk or Clay/Ndom): According to the findings of this study, "Ndo" in "Oro culture" can be used to communicate the proof of innocence of a certain accusation. All that will be done is to dab the innocent all over with white clay. This way, the innocent is validated and he/she will be proud to appear in the public and belong among men of impeccable character, trusted for public office.

5) "Nkang" (Charcoal): It is used to mark a confirmed thief, or witch or wizard, which is emblematic of disgrace, failure, taboo and shame. It is also a symbol of misery, rejection, dejection and frustration. Once the guilty is rubbed all over with charcoal, he/she must be satisfied to live with rejection most of the lifetime. The

Table 13. Respondents' understanding of the messages rendered through the selected symbols.

\begin{tabular}{ccc}
\hline Options & Frequency & Percentage \\
\hline Yes & 256 & 88.83 \\
No & 32 & 11.17 \\
Total & $\mathbf{2 8 8}$ & $\mathbf{1 0 0}$ \\
\hline
\end{tabular}

Table 14. Respondents' attitude to use of selected symbols in traditional communication.

\begin{tabular}{lcc}
\multicolumn{1}{c}{ Significance } & No. of Respondents & Percentage \\
\hline Would regard as valid & 202 & 70.21 \\
Would regard as outmoded & 58 & 19.95 \\
Would regard them as contrary to religious beliefs & 28 & 9.84 \\
Total & $\mathbf{2 8 8}$ & $\mathbf{1 0 0}$ \\
\hline
\end{tabular}

Table 15. Respondents' perception of effectiveness of Oro traditional communication compared to modern media of communication.

\begin{tabular}{ccc}
\hline Options & Frequency & Percentage \\
\hline Yes & 172 & 59.84 \\
No & 116 & 40.16 \\
Total & $\mathbf{2 8 8}$ & $\mathbf{1 0 0}$ \\
\hline
\end{tabular}


communicative value of this symbol in "Oro" culture agrees with Udosen (2009) and Antia (2005) with regard to Nkang as a symbol of shame.

6) “Obio Utong” (Special String): As a symbol, "Obio Utong” is recognized by Oro people to indicate warning and or reminding concerned parties of a taken decision. This also has a binding effect with regards to conflict resolution.

7) "Mmong" (Water): Among the "Oros" mmong is a key instrument in the amicable settlement of conflict when shared and drank from a common or one cup by former disputants. Once a sip is taken, it is taken that forgiveness has resulted and peace is obtained in the matter.

8) “Ukpong” (Horn, Trumpet, Nnuk Enang): It is used as a medium to summon people to a meeting for urgent solution to a conflict.

From the foregoing, this study has been able to establish that these symbols still serve as veritable means of communication among the "Oro People" and are found to be effective and valid when deployed in conflicts resolution, as they are binding within the context of usage. Their significance cannot therefore be overemphasized.

\section{Conclusions}

Conflicts have been known to be a product of life and living: among human beings, differences in opinions, attitudes, and behaviors have often time resulted in conflict. In traditional communities, dating back to primordial times, a system of adjudication existed, which employed the use of certain instruments, items, elements, objects and symbols.

Today, these methods and modes thrive among the "Oro" people in Oron Local Government Area of Akwa Ibom State. Their credibility and efficacy are still intact as various traditional modes have been used, and are still being used to transmit important and strategic messages to the "Oro" people when, for instance, Ogbin is placed as an injunction on a property under dispute and Olughu used to establish the truth in a matter.

Preserving this cultural heritage is of prime importance to the "Oro" people; hence they still organize festivals and ceremonies to highlight the communicative value of their traditional symbols. A combination of these traditional modes with modern systems of communication and more education on their significance would probably engender interest and appreciation of what they stand for, especially in the resolution of conflicts.

\section{Recommendations}

Having galvanized the various findings garnered in this work, the following recommendations become imperative:

1) The teaching of traditional communication symbolism in schools to avoid cultural alienation.

2) Inclusion of traditional symbols and mode of communication as potent means of Alternative Dispute Resolution (ADR).

3) Active participation of custodians of traditional instruments in panels of enquiries and conflict resolution.

4) Adoption of trado-modern system of communication.

\section{References}

[1] Obasi, N.T. (2008) The Relevance of Traditional Mode of Communication in Contemporary Nigerian Society. International Journal of Communication, 8, 14-24.

[2] McBride, S. (1980) Many Voices, One World: Communication Today and Tomorrow. UNESCO, Paris.

[3] Udoh, C.T. (1989) Communication and the Resolution of Cultural Conflicts in Nigeria. In: Akpan, E., Ed., Cultural Week 87, University of Cross River State (UNICROSS), Nigeria, 17-18.

[4] Udosen, E.R. (2009) Uyo Residents' Perception of the Comparative Value of Iconographic Symbols in Traditional Communication System. B.A. Degree (Unpublished), University of Uyo, Nigeria.

[5] Federal Republic of Nigeria, Official Gazette (2009) Abuja: Federal Ministry of Information.

[6] Uya, O.E. (1984) History of Oron People of the Lower Cross River Basin. Mawson Publishers, Oron.

[7] Katz, D. and Kahn, R.I. (1978) The Sociology and Psychology of Organization. John Wesley and Sons, New York.

[8] Udall, R. and Udall, S. (1979) Meaning of Communication. In: Sybil, J., Ode, I. and Soola, O., Eds., Introduction to Communication for Business Organizations, Spectrum Books Ltd., Ibadan, 20-34.

[9] Eyre, E.C. (1983) Effective Communication Made Simple. In: Sybil, J., Ode, I. and Soola, O., Eds., Introduction to 
Communication for Business Organizations, Spectrum Books Ltd., Ibadan, 23-34.

[10] Akpan, E.D. (1987) Communication and Media Arts: A New Approach to the Basics. Modern Business Press Limited, Uyo.

[11] Akpan, E.D. (1993) Prologue to Communication Understanding. 2nd Edition, Modern Business Press Limited, Uyo.

[12] Dominick, J.R. (2002) The Dynamics of Mass Communication. McGraw Hills Companies Inc., New York.

[13] Gamble, T. and Gamble, M. (2002) Communication Works. McGraw Hill Inc., Boston.

[14] Okunna, C.S. (2002) Teaching Mass Communication: A Multi-Dimensional Approach. New Generation Books, Enugu.

[15] McQuail, D. (2005) McQuail’s Mass Communication Theory. 5th Edition, Sage Books, Los Angeles.

[16] Littlejohn, S. and Foss, K. (2005) Theories of Human Communication. 9th Edition, Thomson and Wadsworth, Canada.

[17] Wilson, D. (2006) Speech, Proverb and Folklore Aesthetics in Traditional African Communication. Journal of Media and Aesthetics, 2, 13-24.

[18] Hoffman, M. (2007) Academic’s Dictionary of Mass Communication. Academic (India) Publishers, New Delhi. http://www.managementstudyguide.compublicrelation.htm

[19] Bitner, J. (1989) Mass Communication: An Introduction. Prentice Hall Publishing Coy, Upper Saddle River.

[20] Okunna, C.S. (1994) Introduction to Mass Communication. New Generation Books, Enugu.

[21] Okpoko, J. (2005) Understanding Mass Media and Society. ABIC Publishers, Enugu.

[22] Koontz, H. (2001) Management: A Global Perspective. 10th Edition, McGraw-Hill Inc., New York.

[23] Ugboajah, F.O. (1985) Mass Communication, Culture and Society in West Africa. Hans, New York.

[24] Wilson, D. (1989) Traditional Instruments of Communication in Akwa Ibom State. In: Akpan, E.D., Ed., Campus Sentinel, University of Cross River State, Uyo, 30-32.

[25] Owens-Ibie, N. (2002) Socio-Cultural Considerations in Conflict Reporting in Nigeria. In: Pate, U.A., Ed., Introduction to Conflict Reporting in Nigeria, Frankad Publishers, Lagos, 30-44.

[26] Ibrahim, G. (2002) Conflict in Democracies. In: Pate, U.A., Ed., Introduction to Conflict Reporting in Nigeria, Frankad Publishers, Lagos, 18-29.

[27] Udomisor, I.W. (2002) Problems and Prospects of Reporting Conflict in a Democracy: The Editors' Challenge. In: Pate, U.A., Ed., Introduction to Conflict Reporting in Nigeria, Frankad Publishers, Lagos, 84-98.

[28] Etuk, U. (1989) The Dialectics of Culture. Cultural Week 89, University of Cross River State, Uyo.

[29] Williams, F. (1989) New Communications. Wadsworth Publishing Company, Belmont.

[30] Wilson, D. (1990) Traditional Communication Media System. In: Akpan, E.D., Ed., Communication Arts: Principles, Applications and Practices, Modern Business Press Ltd., Uyo, 80-81.

[31] Okonkwo, R. and Ekwelie, U. (1983) Communication in Transition: A Case Study of Igboland. Nigeria Magazine, No. 144, p. 46.

[32] Shaefer, R. and Lamm, R. (1995) Sociology. McGraw Hill Inc., London.

[33] Ritzer, G. (1996) Sociological Theory. McGraw Hill Companies Inc., New York.

[34] Ansu-Kyremah, K. (1998) Perspectives of Indigenous Communication in Africa. School of Communication Studies, Legon.

[35] Reuben, B. (1988) Communication and Human Behaviour. MacMillan Publishing Company, New York.

[36] Udeze, S.E. (2005) After the Whirlwind: A Discourse on International Communication. Rhyce Kerex Publishers, Enugu.

[37] Eneobong, U.I. (2007) Traditional Communication in Annangland: Issues, Problems and Prospects. Department of Communication Arts, University of Uyo, Uyo.

[38] Udoekong, G.E. (2013) Communicative Significance of Select Traditional Symbols in Oron Local Government Area. Department of Communication Arts, University of Uyo, Uyo.

[39] Effanga, M.E. (1989) Ibibio Traditional Regard for “UKOD”, “IMAN” and “AYEYIN” Relationship. Cultural Week 89, University of Cross River State (UNICROSS), Uyo.

[40] Antia, R.U. (2005) Akwa Ibom Cultural Heritage, Its Invasion by Western Culture and Its Renaissance. Abbny Publishers, Uyo.

[41] Wilson, D. (2006) Basic African Communication Systems. In: Wilson, D., Ed., Fundamentals of Human Communication, Stirling-Horden Publishers Ltd., Ibadan, 5-12.

[42] Ekong, E.E. (2001) Sociology of the Ibibios: A Study of Social Organization and Change. Modern Business Press, Calabar. 
Scientific Research Publishing (SCIRP) is one of the largest Open Access journal publishers. It is currently publishing more than 200 open access, online, peer-reviewed journals covering a wide range of academic disciplines. SCIRP serves the worldwide academic communities and contributes to the progress and application of science with its publication.

Other selected journals from SCIRP are listed as below. Submit your manuscript to us via either submit@scirp.org or Online Submission Portal.
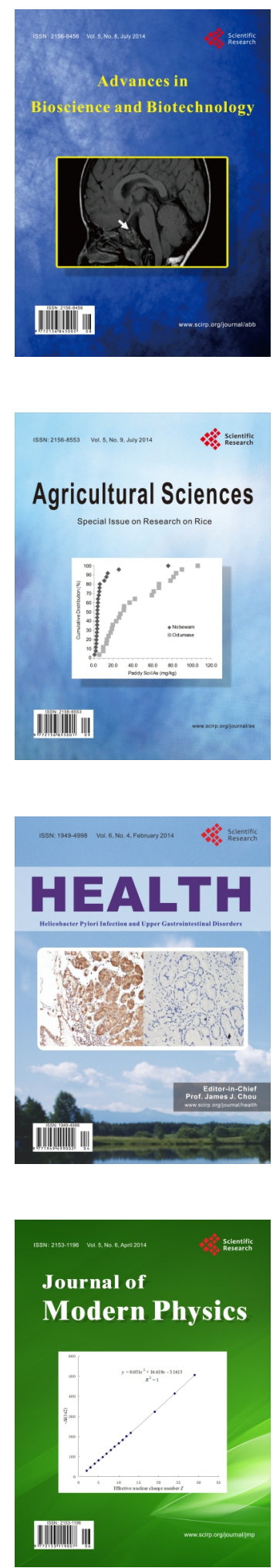
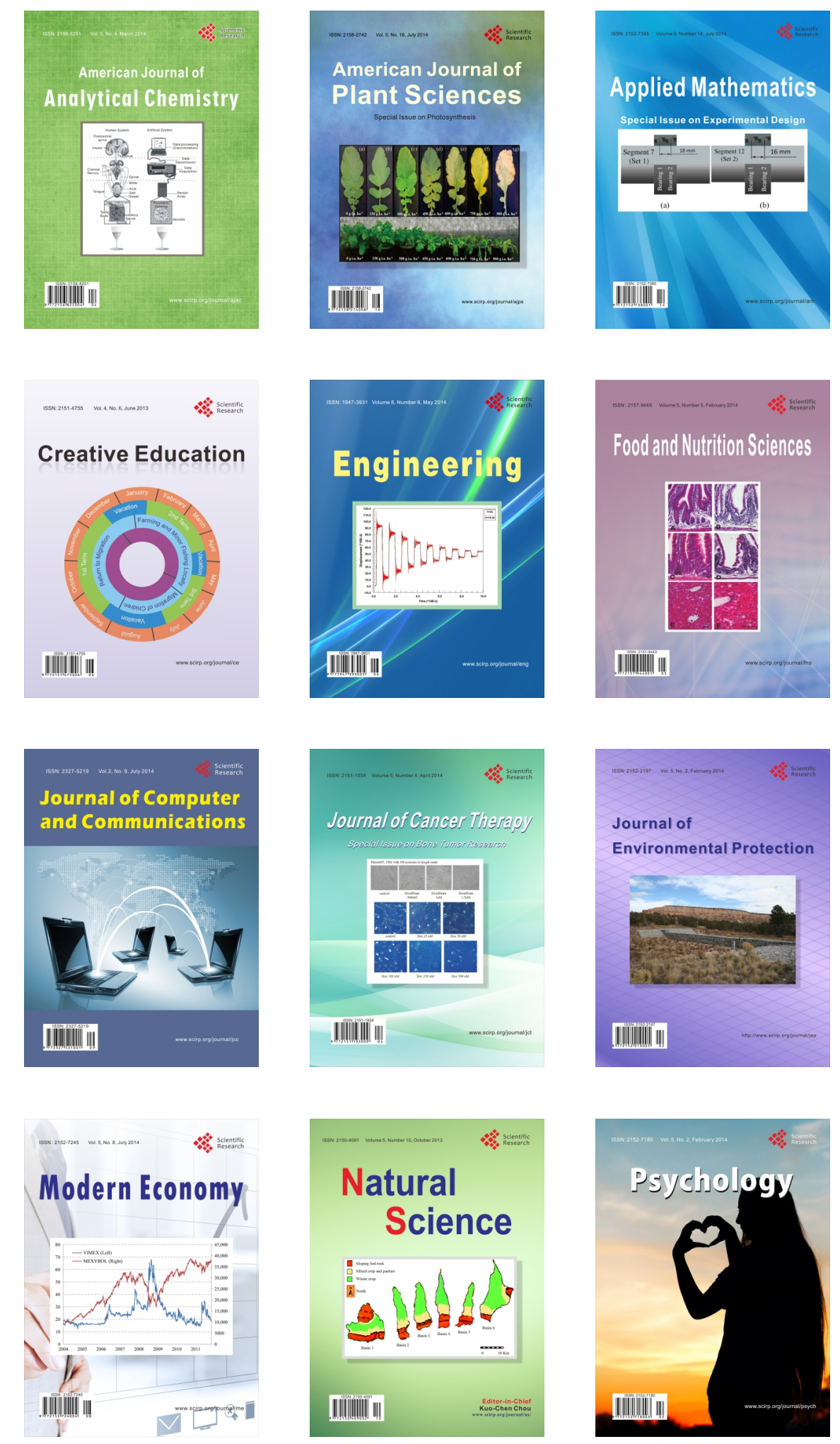